\title{
Naturally occurring basal core promoter A1762T/G1764A dual mutations increase the risk of HBV-related hepatocellular carcinoma: a meta-analysis
}

\author{
Zongguo Yang ${ }^{1, *}$, Liping Zhuang ${ }^{2,3, *}$, Yunfei $\mathrm{Lu}^{1}$, Qingnian $X \mathbf{u}^{1}$, Bozong Tang ${ }^{1}$ and \\ Xiaorong Chen ${ }^{1}$ \\ ${ }^{1}$ Shanghai Public Health Clinical Center, Fudan University, Shanghai, China \\ ${ }^{2}$ Fudan University Shanghai Cancer Center, Shanghai, China \\ ${ }^{3}$ Shanghai Medical College, Fudan University, Shanghai, China \\ * These authors have contributed equally to this work \\ Correspondence to: Xiaorong Chen, email: xiaorong3chen@163.com \\ Zongguo Yang, email: dr_yangzg@aliyun.com \\ Keywords: hepatitis B virus X protein, hepatocellular carcinoma, basal core promoter, mutation, A1762T/G1764A \\ Received: October 05, $2015 \quad$ Accepted: January 23, $2016 \quad$ Published: Febraury 02, 2016
}

\section{ABSTRACT}

Basal core promoter (BCP) A1762T/G1764A dual mutations in hepatocarcinogenesis remain controversial. Published studies up to June 1, 2015 investigating the frequency of A1762T/G1764A dual mutations from chronic hepatitis $B$ virus (HBV) infection, including hepatocellular carcinoma (HCC), were systematically identified. A total of 10,240 patients with chronic HBV infection, including 3729 HCC cases, were included in $\mathbf{5 2}$ identified studies. HCC patients had a higher frequency of BCP A1762T/G1764A dual mutations compared with asymptomatic HBsAg carriers (ASC) and patients with chronic hepatitis B (CHB) and liver cirrhosis (LC) (OR = 5.59, $P<0.00001 ;$ OR $=2.87, P<0.00001 ; O R=1.55, P=0.02$, respectively). No statistically significant difference was observed in the frequency of A1762T/G1764A dual mutations in cirrhotic HCC versus non-cirrhotic HCC patients $(O R=2.06, P$ $=0.05)$. Chronic HBV-infected patients and HCC patients with genotype $B$ had a significantly lower risk of A1762T/G1764A dual mutations compared with patients with genotype $C(O R=0.30, P<0.0001$ and $O R=0.34, P=0.04$, respectively). In HBV genotype $C$ subjects, A1762T/G1764A dual mutations contributed to significantly higher risk for HCC developing compared with non-mutation ones (OR = 3.47, P < 0.00001 ). In conclusion, A1762T/G1764A dual mutations increase the risk of HBVrelated hepatocellular carcinoma, particularly in an HBV genotype C population, even without progression to cirrhosis.

\section{INTRODUCTION}

Viral genomic mutations may contribute to HCC development. HBV nonstructural X protein (HBx) is a key regulatory protein of the virus and is at the intersection of HBV infection, replication, pathogenesis, and possibly carcinogenesis. HBx has different consequences for hepatocyte physiology because HBV-infected cells are targeted by the immune system or as hepatocytes, in which HBx is expressed, and undergo transformation and progression to HCC. In addition, HBx can influence apoptotic and cell cycle regulatory pathways [1].
However, the roles that $\mathrm{HBx}$ mutations play in hepatocarcinogenesis remain controversial, particularly for the basal core promoter (BCP) A1762T/G1764A dual mutation. Several prospective studies have demonstrated that patients with an A1762T/G1764A dual mutation were more predisposed to HCC than those with the wild type and that HBV mutations, including A1762T/ G1764A, are associated with an increased risk of HCC [2]. However, a recent study using global data found no significant difference in BCP mutations between $\mathrm{HCC}$ and non-HCC patients with $\mathrm{HBV}$ genotype $\mathrm{C}$, and the differences between chronic hepatitis $\mathrm{B}$ (CHB) and liver cirrhosis (LC) and between LC and HCC were not 
significant, although the mutant ratio increased with disease progression. [3].

In this meta-analysis, we summarized the prevalence of A1762T/G1764A mutations from ASC, $\mathrm{CHB}, \mathrm{LC}$ and HCC patients. We also analyzed the BCP mutation rates in chronic $\mathrm{HBV}$ infection, including $\mathrm{HCC}$ patients grouped by HBV genotype and $\mathrm{HBeAg}$ status, hoping that the results might provide useful insights into the risk of HCC occurrence.

\section{RESULTS}

\section{Study and patient characteristics}

A total of 1883 abstracts were reviewed. From these articles, 163 that were closely related to the current subject were retrieved. The study selection process is summarized in Figure 1. Finally, 52 case-control or cohort studies [455] were included in the meta-analysis. A total of 10,240 individuals with chronic $\mathrm{HBV}$ infection were included, 3729 of whom had HCC. The baseline characteristics and quality scores of the studies examined in this metaanalysis are listed in Table 2.

\section{Prevalence of A1762T/G1764A mutations from ASC, CHB, LC and HCC}

Heterogeneity was significant among the included studies [4-38, 40-55] when comparing the prevalence of A1762T/G1764A dual mutations between HCC and non-HCC patients $\left(P<0.00001, \mathrm{I}^{2}=82 \%\right)$. Thus, a random-effects model was used. Our data revealed that more HCC patients had A1762T/G1764A dual mutations

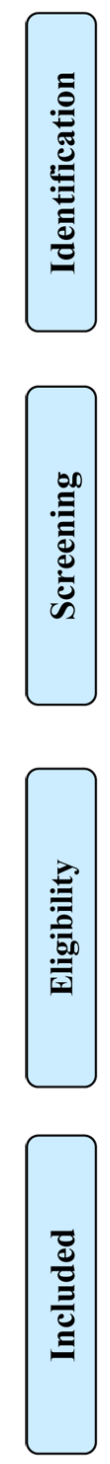

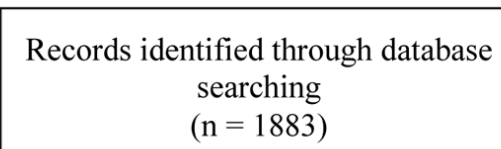

$(\mathrm{n}=1883)$

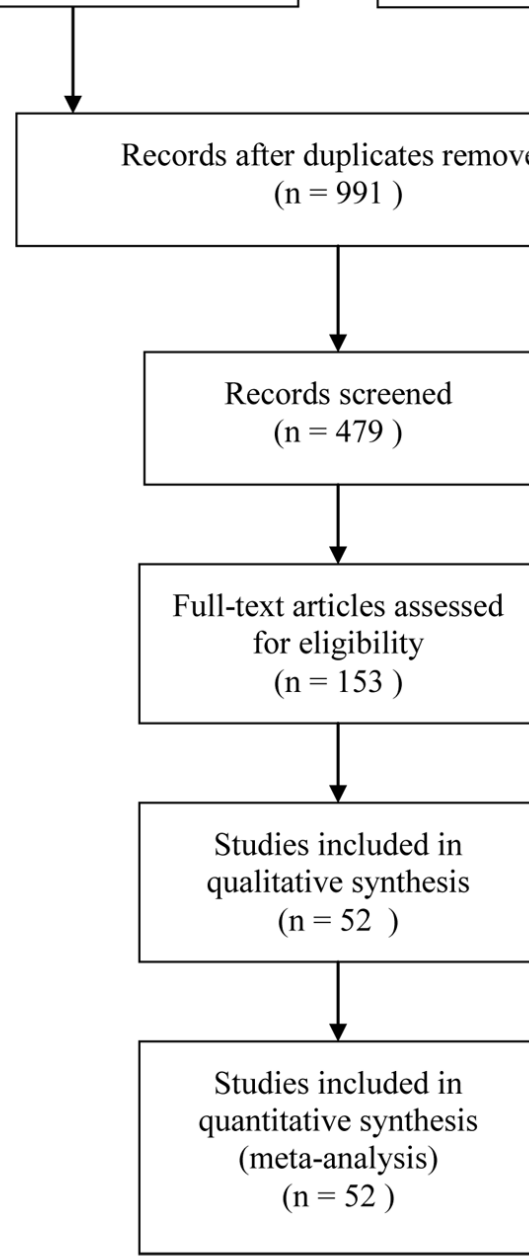

No additional records identifid through other sources
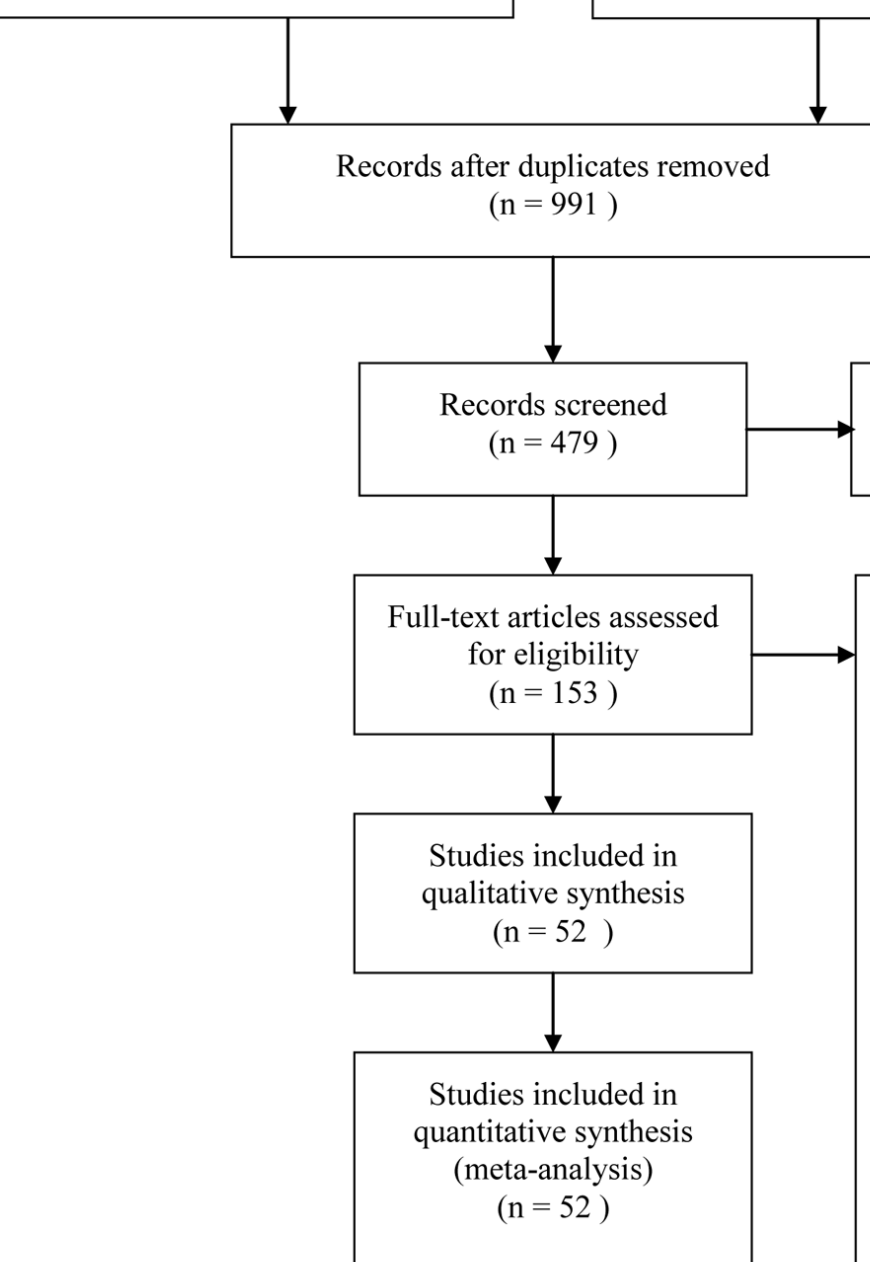

Records excluded $(\mathrm{n}=512)$

Figure 1: Flow program of study selection. 
Table 1: Quality criteria for the included studies*

\begin{tabular}{|c|c|c|c|}
\hline \multirow{2}{*}{ Quality parameter } & \multicolumn{3}{|c|}{ Score } \\
\hline & 2 & 1 & $\mathbf{0}$ \\
\hline Study design & $\begin{array}{l}\text { Cohort study or nested case- } \\
\text { control study }\end{array}$ & $\begin{array}{l}\text { Incidence case-control study. } \\
\text { Prevalence case-control study }\end{array}$ & - \\
\hline No. of case subjects & $>100$ & $50-100$ & $<50$ \\
\hline Source of population & $\begin{array}{l}\text { Community-based or from two } \\
\text { or more countries }\end{array}$ & $\geq 2$ hospitals & 1 hospitals \\
\hline Mutation detection method & DNA direct sequencing & Innogenetics line-probe assay & $\begin{array}{l}\text { Single-strand } \\
\text { conformation } \\
\text { polymorphism; Mass } \\
\text { spectrometer }\end{array}$ \\
\hline $\begin{array}{l}\text { Matching of case and control } \\
\text { subjects }\end{array}$ & & & \\
\hline Confounder group 1 & Age and sex & Age or sex & None \\
\hline Confounder group 2 & \begin{tabular}{|llll}
$\begin{array}{l}\mathrm{HBeAg} \\
\text { genotype }\end{array}$ & status and $\mathrm{HBV}$ \\
\end{tabular} & HBeAg status or HBV genotype & None \\
\hline
\end{tabular}

* -, designs other than cohort or nested, incidence, or prevalence case-control not included in meta-analysis; HBeAg, hepatitis B e antigen; HBV, hepatitis B virus.

Table 2: Baseline characteristics of studies included in the meta-analysis

\begin{tabular}{|c|c|c|c|c|c|c|c|c|c|c|c|}
\hline \multirow[b]{2}{*}{ Study } & \multirow[b]{2}{*}{ Design } & \multirow{2}{*}{$\begin{array}{l}\text { Country or } \\
\text { area }\end{array}$} & \multirow{2}{*}{$\begin{array}{l}\text { No. of } \\
\text { cases }\end{array}$} & \multirow{2}{*}{$\begin{array}{l}\text { No. of } \\
\text { controls }\end{array}$} & \multirow{2}{*}{$\begin{array}{l}\text { Detection } \\
\text { method }\end{array}$} & \multirow{2}{*}{$\begin{array}{l}\text { HBV } \\
\text { genotype }\end{array}$} & \multicolumn{4}{|c|}{ Matching factors } & \multirow{2}{*}{$\begin{array}{l}\text { Quality } \\
\text { score }\end{array}$} \\
\hline & & & & & & & Age & Sex & \begin{tabular}{|l|}
$\begin{array}{l}\text { HbeAg } \\
\text { status }\end{array}$ \\
\end{tabular} & \begin{tabular}{|l|} 
HBV \\
genotype
\end{tabular} & \\
\hline Asim 2010 & PCC & India & 150 & 136 & SSCP & $\mathrm{A}, \mathrm{D}$ & - & - & - & - & $\leq 4$ \\
\hline $\begin{array}{l}\text { Bahramali } \\
2008\end{array}$ & Cohort & Iran & 7 & 55 & Sequencing & $\mathrm{D}$ & - & - & - & - & $\leq 4$ \\
\hline Bai 2011 & Cohort & China & 152 & 136 & Sequencing & \begin{tabular}{|l|} 
B, C, \\
others
\end{tabular} & - & - & - & - & 7 \\
\hline Baptista 1999 & PCC & South Africa & 59 & 52 & Sequencing & NA & + & - & - & - & $5-7$ \\
\hline $\begin{array}{l}\text { Blackberg } \\
2003\end{array}$ & PCC & $\begin{array}{l}\text { Sweden, } \\
\text { others }\end{array}$ & 16 & 19 & Sequencing & $\begin{array}{l}\text { A, B, C, } \\
\text { D }\end{array}$ & - & + & + & + & $\geq 8$ \\
\hline Chen 2006 & PCC & Taiwan & 50 & 102 & INNO-LiPA & $\mathrm{B}, \mathrm{C}$ & + & - & - & - & $5-7$ \\
\hline Chen 2008 & $\mathrm{PCC}$ & Taiwan & 80 & 160 & Sequencing & $\mathrm{B}, \mathrm{C}, \mathrm{D}$ & + & + & + & - & $5-7$ \\
\hline Chen 2009 & PCC & Taiwan & 222 & 300 & Sequencing & $\mathrm{B}, \mathrm{C}$ & + & + & - & - & $5-7$ \\
\hline Chen 2012 & PCC & China & 156 & 310 & Sequencing & $\mathrm{B}, \mathrm{C}$ & + & + & - & - & $5-7$ \\
\hline Cho 2011 & PCC & Korea & 69 & 125 & Sequencing & $\mathrm{C}$ & - & - & - & - & $\leq 4$ \\
\hline Choi 2009 & PCC & Korea & 42 & 46 & Sequencing & $\mathrm{C}$ & - & - & - & - & $\leq 4$ \\
\hline Chou 2008 & $\mathrm{NCC}$ & Taiwan & 154 & 316 & Sequencing & $\mathrm{A}, \mathrm{B}, \mathrm{C}$ & + & - & - & - & $\geq 8$ \\
\hline Chu 2012 & PCC & Taiwan & 80 & 120 & Sequencing & $\mathrm{B}, \mathrm{C}$ & + & + & + & - & $4-6$ \\
\hline $\begin{array}{l}\text { Constantinescu } \\
2014\end{array}$ & Cohort & Romania & 94 & 390 & Sequencing & A, D & - & - & - & - & 5 \\
\hline Datta 2014 & PCC & India & 22 & 46 & Sequencing & $\mathrm{A}, \mathrm{C}, \mathrm{D}$ & - & - & - & - & $\leq 4$ \\
\hline Elkady 2008 & PCC & Mongolia & 23 & 25 & Sequencing & $\mathrm{A}, \mathrm{D}$ & - & - & - & - & $\leq 4$ \\
\hline Fan 2011 & PCC & China & 34 & 38 & Sequencing & $\mathrm{B}, \mathrm{C}$ & + & + & + & - & $5-7$ \\
\hline Guo 2008 & $\mathrm{NCC}$ & China & 58 & 71 & Sequencing & $\mathrm{B}, \mathrm{C}$ & + & + & - & - & $\geq 8$ \\
\hline Ito 2006 & ICC & \begin{tabular}{|l|} 
Japan, \\
United \\
States, Hong \\
Kong \\
\end{tabular} & 40 & 80 & Sequencing & $\mathrm{C}$ & + & + & + & + & $\geq 8$ \\
\hline Jang 2007 & Cohort & Korea & 6 & 23 & Sequencing & C & - & - & + & + & $\geq 8$ \\
\hline Kao 2012 & PCC & Taiwan & 56 & 112 & Sequencing & $\mathrm{B}, \mathrm{C}$ & + & - & - & - & $4-5$ \\
\hline Kim 2008 & PCC & Korea & 60 & 124 & Sequencing & $\mathrm{C}$ & - & - & - & + & $5-7$ \\
\hline Kim 2009 & PCC & \begin{tabular}{|l|} 
Korea \\
\end{tabular} & 135 & 135 & Sequencing & $\mathrm{C}$ & + & + & + & - & $5-7$ \\
\hline Kuang 2005 & PCC & Thailand & 34 & 68 & \begin{tabular}{|l|} 
Mass \\
spectrometer
\end{tabular} & NA & + & + & - & - & $\leq 4$ \\
\hline
\end{tabular}




\begin{tabular}{|c|c|c|c|c|c|c|c|c|c|c|c|}
\hline Lee 2011 & PCC & Korea & 31 & 65 & Sequencing & C & - & - & - & - & $\leq 4$ \\
\hline Li 2013 & Cohort & China & 102 & 105 & Sequencing & $\mathrm{C}$ & - & - & - & - & 6 \\
\hline Lin 2005 & PCC & Taiwan & 32 & 142 & Sequencing & $\begin{array}{l}\mathrm{B}, \quad \mathrm{C}, \\
\text { Others }\end{array}$ & - & - & + & - & $\leq 4$ \\
\hline Liu 2006 & PCC & Taiwan & 200 & 160 & INNO-LiPA & $\mathrm{B}, \mathrm{C}$ & - & - & - & - & $\leq 4$ \\
\hline $\begin{array}{l}\text { Livingston } \\
2007\end{array}$ & ICC & $\begin{array}{l}\text { United } \\
\text { States }\end{array}$ & 47 & 1129 & INNO-LiPA & $\begin{array}{l}\mathrm{A}, \mathrm{C}, \mathrm{D}, \\
\mathrm{F}\end{array}$ & + & + & - & - & $\leq 4$ \\
\hline Lyu 2013 & ICC & Korea & 318 & 234 & Sequencing & C & - & - & - & - & 5 \\
\hline Malik 2012 & PCC & India & 118 & 294 & Sequencing & $\mathrm{A}, \mathrm{D}$ & - & - & - & - & 5 \\
\hline $\begin{array}{l}\text { Muroyama } \\
2006\end{array}$ & PCC & Japan & 39 & 36 & Sequencing & $\mathrm{C}$ & + & + & - & + & $5-7$ \\
\hline Panigrahi 2012 & PCC & India & 20 & 132 & Sequencing & $\mathrm{A}, \mathrm{C}, \mathrm{D}$ & - & - & - & - & $\leq 4$ \\
\hline Park 2014 & PCC & Korea & 132 & 310 & Sequencing & $\mathrm{C}$ & - & - & - & - & 5 \\
\hline Qu 2014 & ICC & \begin{tabular}{|l} 
China \\
\end{tabular} & 152 & 131 & Sequencing & $\mathrm{B}, \mathrm{C}$ & + & - & - & - & $5-7$ \\
\hline $\begin{array}{l}\text { Sakamoto } \\
2006\end{array}$ & PCC & $\begin{array}{l}\text { Japan, } \\
\text { Philippines }\end{array}$ & 31 & 69 & Sequencing & $A, B, C$ & - & + & - & - & $5-7$ \\
\hline Shinkai 2007 & PCC & Japan & 80 & 80 & Sequencing & $\mathrm{C}$ & + & + & + & + & $\geq 8$ \\
\hline Song 2005 & PCC & Vietnam & 48 & 74 & Sequencing & NA & - & - & - & - & $\leq 4$ \\
\hline Tanaka 2006 & PCC & $\begin{array}{l}\text { Japan, Hong } \\
\text { Kong }\end{array}$ & 148 & 180 & Sequencing & $\mathrm{C}$ & + & + & + & - & $\geq 8$ \\
\hline $\begin{array}{l}\text { Tangkijvanich } \\
2010\end{array}$ & ICC & Thailand & 60 & 60 & Sequencing & B, C & + & + & + & + & 6 \\
\hline Tong 2007 & ICC & \begin{tabular}{|l} 
United \\
States \\
\end{tabular} & 101 & 67 & Sequencing & $\begin{array}{l}\text { A, B, C, } \\
\text { D }\end{array}$ & - & - & - & - & $5-7$ \\
\hline Tong 2013 & ICC & $\begin{array}{l}\text { United } \\
\text { States }\end{array}$ & 173 & 240 & Sequencing & $\begin{array}{l}\mathrm{A}, \mathrm{B}, \mathrm{C}, \\
\mathrm{D}, \mathrm{E}, \mathrm{F}\end{array}$ & + & - & - & - & $5-7$ \\
\hline Truong 2007 & PCC & $\begin{array}{l}\text { Japan, } \\
\text { Vietnam }\end{array}$ & 32 & 88 & Sequencing & C & - & - & + & + & $5-7$ \\
\hline Utama 2009 & PCC & Indonesia & 48 & 123 & Sequencing & $\mathrm{B}, \mathrm{C}$ & - & - & - & - & 5 \\
\hline Wang 2007 & PCC & China & 47 & 164 & Sequencing & $\mathrm{B}, \mathrm{C}$ & - & + & - & - & $5-7$ \\
\hline Xu 2010 & PCC & China & 60 & 120 & Sequencing & $\mathrm{A}, \mathrm{B}, \mathrm{C}$ & + & + & - & - & $4-6$ \\
\hline Yin 2011 & PCC & China & 190 & 1269 & Sequencing & $\mathrm{B}, \mathrm{C}$ & + & + & - & - & $\geq 8$ \\
\hline Yuan 2007 & PCC & China & 34 & 207 & Sequencing & $\mathrm{B}, \mathrm{C}$ & - & + & - & + & $5-7$ \\
\hline Yuan 2009 & ICC & China & 49 & 97 & Sequencing & NA & + & - & - & - & $5-7$ \\
\hline Zhang 2007 & Cohort & China & 32 & 32 & Sequencing & NA & + & + & - & - & $6-8$ \\
\hline Zheng 2011 & PCC & China & 156 & 185 & Sequencing & $\mathrm{B}, \mathrm{C}, \mathrm{E}$ & - & - & - & - & 7 \\
\hline Zhu 2008 & $\mathrm{NCC}$ & China & 20 & 83 & Sequencing & C & + & + & + & + & $\geq 8$ \\
\hline
\end{tabular}

Abbreviations: NA, not available; PCC, prevalence case-control; NCC, nested case-control; ICC, incidence case-control; SSCP, Single-strand conformation polymorphism; INNO-LiPA, Innogenetics line-probe assay.

compared with non-HCC patients $(66.5 \%$ vs. $39.8 \%$, OR $=3.05,95 \% \mathrm{CI}=2.35-3.95, P<0.00001$, Table 3 and Supplementary Figure S1).

In addition, we performed a subgroup analysis to compare A1762T/G1764A dual mutations between ASC, $\mathrm{CHB}, \mathrm{LC}$ and HCC patients. Compared to LC patients, HCC patients had a higher risk of A1762T/G1764A dual mutations $(\mathrm{OR}=1.55,95 \% \mathrm{CI}=1.06-2.26, P=0.02$, Table 3 and Supplementary Figure S2). Moreover, a subgroup analysis of four studies [12, 16, 47, 54] with a random-effects model revealed no statistically significant difference between cirrhotic HCC (LC-HCC) and noncirrhotic HCC (non-LC-HCC) patients in terms of the frequency of A1762T/G1764A dual mutations $(\mathrm{OR}=2.06$, $95 \%$ CI $=0.99-4.28, P=0.05$, Table 3 and Supplementary
Figure S3). This result should be reevaluated in studies with larger samples sizes. We performed another comparison of BCP dual mutations between non-LC-HCC and non-LC patients, including CHB and ASC patients. Using a random-effects model, a meta-analysis of four studies [12, 16, 47, 54] showed that the non-LC-HCC patients had a significantly higher frequency of A1762T/ G1764A dual mutations compared with the CHB and ASC patients $(\mathrm{OR}=2.16,95 \% \mathrm{CI}=1.08-4.32, P=0.03$, Table 3 and Supplementary Figure S4). Given the above results, we assumed that BCP A1762T/G1764A dual mutations might promote hepatocarcinogenesis even without progression to cirrhosis.

Additionally, A1762T/G1764A dual mutations contributed to a higher risk of HCC occurrence compared 
Table 3: Frequency of BCP A1762T/G1764A dual mutations from chronic HBV-infected patients, including HCC

\begin{tabular}{|c|c|c|c|c|c|c|c|c|c|}
\hline \multirow[b]{2}{*}{ Comparisons } & \multirow[b]{2}{*}{ Studies } & \multirow{2}{*}{\begin{tabular}{lr|} 
A1762T/ & \\
G1764A & dual \\
mutation, & n \\
\multicolumn{1}{c}{$\%)$} &
\end{tabular}} & \multicolumn{4}{|c|}{ Heterogeneity } & \multirow[b]{2}{*}{ OR } & \multirow[b]{2}{*}{$95 \% \mathrm{CI}$} & \multirow[b]{2}{*}{$P$ value } \\
\hline & & & $\mathrm{Chi}^{2}$ & df & $\mathbf{P}$ & $\begin{array}{l}I^{2} \\
(\%)\end{array}$ & & & \\
\hline $\mathrm{HCC}$ & \multirow{2}{*}[4-38,40-55]{} & $\begin{array}{l}2480 / 3729 \\
(66.5)\end{array}$ & \multirow{2}{*}{270.4} & \multirow{2}{*}{50} & \multirow{2}{*}{$<0.00001$} & \multirow{2}{*}{82} & \multirow{2}{*}{3.05} & \multirow{2}{*}{$\begin{array}{l}2.35- \\
3.95\end{array}$} & \multirow{2}{*}{$\begin{array}{l}< \\
0.00001\end{array}$} \\
\hline Non-HCC & & $\begin{array}{l}2594 / 6511 \\
(39.8)\end{array}$ & & & & & & & \\
\hline $\mathrm{HCC}$ & \multirow{2}{*}{$\begin{array}{l}{[5,9,12-14,16,18,23,25,} \\
28, \\
30,34,36,41,46-48,51, \\
55]\end{array}$} & $544 / 808$ (67.3) & \multirow[t]{2}{*}{33.38} & \multirow[t]{2}{*}{18} & \multirow[t]{2}{*}{0.02} & \multirow[t]{2}{*}{46} & \multirow[t]{2}{*}{1.55} & \multirow{2}{*}{$\begin{array}{l}1.06- \\
2.26\end{array}$} & \multirow[t]{2}{*}{0.02} \\
\hline $\mathrm{LC}$ & & $441 / 708(62.3)$ & & & & & & & \\
\hline $\mathrm{HCC}$ & \multirow{2}{*}{$\begin{array}{l}{[5,9,12,13,20-23,25,28-} \\
30, \\
33,34,36,41,47,48,51 \\
53,55]\end{array}$} & $927 / 1300(71.3)$ & \multirow{2}{*}{72.49} & \multirow{2}{*}{20} & \multirow{2}{*}{$<0.00001$} & \multirow{2}{*}{72} & \multirow{2}{*}{2.87} & \multirow{2}{*}{$\begin{array}{l}1.96- \\
4.20\end{array}$} & \multirow{2}{*}{$\begin{array}{l}< \\
0.00001\end{array}$} \\
\hline $\mathrm{CHB}$ & & $796 / 1566(50.8)$ & & & & & & & \\
\hline $\mathrm{HCC}$ & \multirow{2}{*}{$\begin{array}{l}{[5,7-9,16,17,22-25,30,} \\
31, \\
36,41,44,51]\end{array}$} & $591 / 924(64.0)$ & \multirow{2}{*}{70.33} & \multirow{2}{*}{15} & \multirow{2}{*}{$<0.00001$} & \multirow{2}{*}{79} & \multirow{2}{*}{5.59} & & \\
\hline $\mathrm{ASC}$ & & $246 / 1068(23.0)$ & & & & & & 9.83 & 0.00001 \\
\hline LC-HCC & 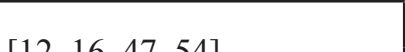 & $327 / 476(68.7)$ & 657 & 3 & 000 & 54 & 206 & $0.99-$ & 005 \\
\hline Non-LC-HCC & {$[12,16,4 /, 54]$} & $93 / 165(56.4)$ & 0.51 & 3 & 0.09 & 54 & 2.00 & 4.28 & 0.05 \\
\hline Non-LC-HCC & {$\left[\begin{array}{llll}12 & 16 & 47 & 54\end{array}\right.$} & $93 / 165(56.4)$ & 760 & 3 & 005 & 61 & 216 & $1.08-$ & 003 \\
\hline $\mathrm{CHB} / \mathrm{ASC}$ & {$[12,10,4 /, 34]$} & $225 / 466(48.3)$ & 1.00 & 3 & 0.05 & 01 & 2.10 & 4.32 & 0.03 \\
\hline
\end{tabular}

Abbreviations: HCC, hepatocellular carcinoma; LC, liver cirrhosis; CHB, chronic hepatitis B; ASC, asymptomatic HBsAg carriers; LC-HCC, cirrhotic hepatocellular carcinoma; Non-LC-HCC, non-cirrhotic hepatocellular carcinoma.

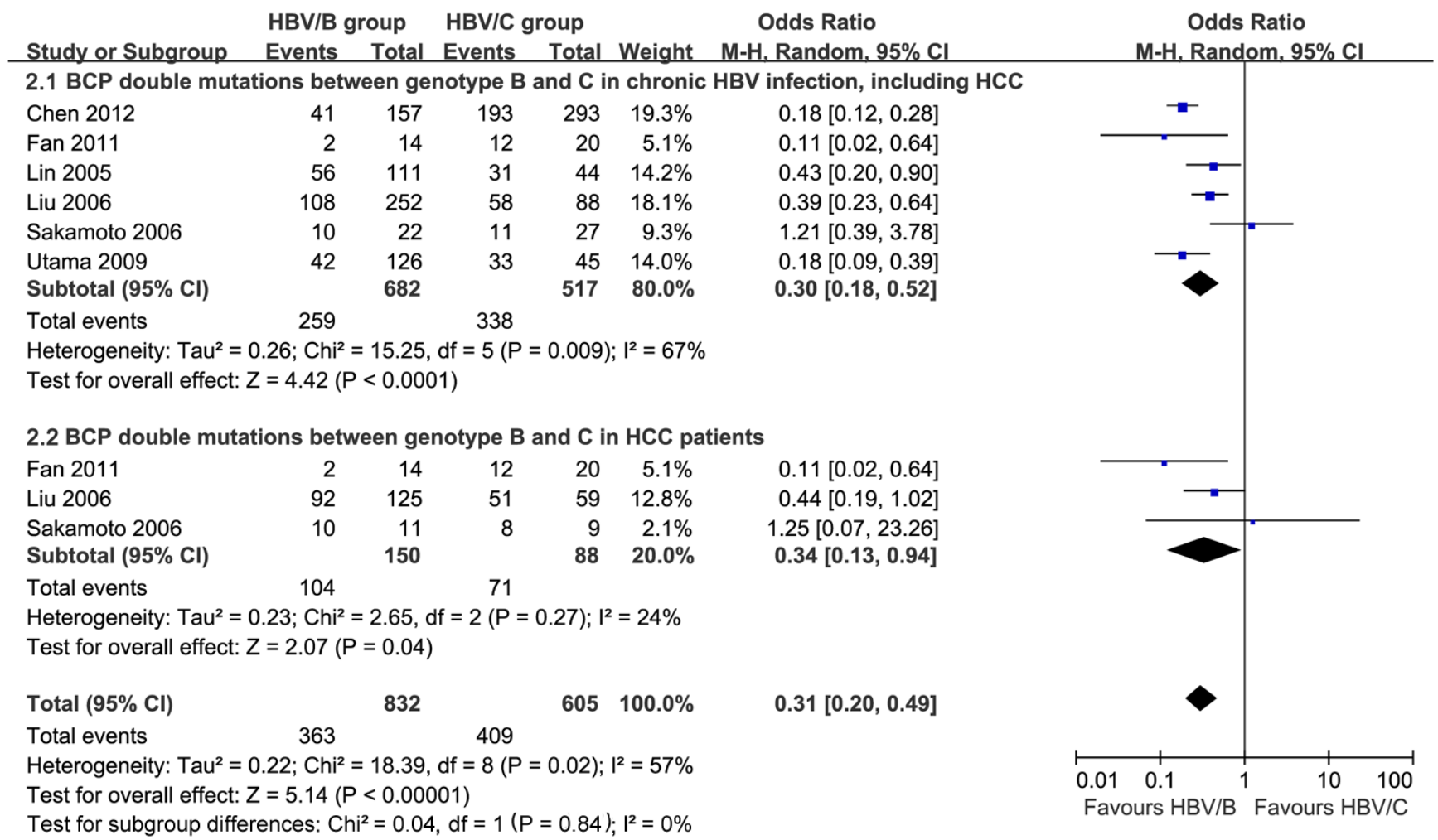

Figure 2: BCP A1762T/G1764A dual mutations in HBV genotype $B$ and $C$ from chronic HBV infection patients, including HCC. 
with $\mathrm{CHB}$ patients $(\mathrm{OR}=2.87,95 \% \mathrm{CI}=1.96-4.20, P$ $<0.00001$, Table 3 and Supplementary Figure S5). A similar trend in A1762T/G1764A dual mutations was found in HCC and ASC patients. HCC patients had a significantly higher frequency of A1762T/G1764A dual mutations than the ASC patients $(\mathrm{OR}=5.59,95 \% \mathrm{CI}=$ 3.17-9.83, $P<0.00001$, Table 3 and Supplementary Figure S6). In summary, the frequency of A1762T/G1764A dual mutations increased in this manner: from ASC to chronic disease, and then to HCC (Supplementary Table S1).

\section{A1762T/G1764A mutations in different $\mathrm{HBV}$ genotypes}

Heterogeneity was significant among the included studies [12, 20, 30, 31, 39, 47], which described A1762T/ G1764A dual mutations from chronic HBV infection in HBV genotypes B and C. Chronic HBV-infected patients with genotype $\mathrm{B}$ had a significant lower incidence of A1762T/G1764A dual mutations compared with those with genotype $\mathrm{C}(\mathrm{OR}=0.30,95 \% \mathrm{CI}=0.18-0.52, P<$ 0.0001 , Figure 2.1); no heterogeneity was found when we compared BCP dual mutations between HBV genotypes $\mathrm{B}$ and $\mathrm{C}$ in HCC patients $\left(P=0.27, \mathrm{I}^{2}=24 \%\right)$. Similarly, HCC patients with HBV genotype B had lower levels of A1762T/G1764A dual mutations compared with those with genotype $\mathrm{C}(\mathrm{OR}=0.34,95 \% \mathrm{CI}=0.13-0.94$, $P=0.04$, Figure 2.2). In $\mathrm{HBV}$ genotype $\mathrm{C}$ subjects, BCP A1762T/G1764A dual mutations contributed to significantly higher risk for HCC developing compared with non-mutation ones $(\mathrm{OR}=3.47,95 \% \mathrm{CI}=2.28-5.27$, $P<0.00001$, Figure 3.1). Heterogeneity was significant between studies comparing HCC occurrence in HBV genotype $\mathrm{B}\left(P<0.00001, \mathrm{I}^{2}=93 \%\right)$, no difference was found $(P=0.34$, Figure 3.2).

\section{A1762T/G1764A mutations from HBeAg-positive and HBeAg-negative patients}

Nine studies [7, 12-14, 29, 37, 40, 42, 54] reported A1762T/G1764A dual mutations based on HBeAg status in chronic HBV infection. Heterogeneity was significant among these studies $\left(\mathrm{P}<0.00001, \mathrm{I}^{2}=81 \%\right)$, and no significance in BCP A1762T/G1764A mutations was observed in either $\mathrm{HBeAg}$-positive or $\mathrm{HBeAg}$-negative chronic $\mathrm{HBV}$-infected patients $(\mathrm{OR}=1.06,95 \% \mathrm{CI}=$ $0.63-1.78, P=0.83$, Figure 4.1). In HCC, there was no difference of A1762T/G1764A mutations between $\mathrm{HBeAg}$-positive and $\mathrm{HBe} A g$-negative patients $(\mathrm{OR}=$ $1.38,95 \% \mathrm{CI}=0.84-2.27, P=0.20$, Figure 4.2 ).

\section{DISCUSSION}

HCC is one of the most lethal cancers [56, 57]. The most common naturally occurring mutations in the BCP A1762T/G1764A dual mutation has been associated with hepatocarcinogenesis, but conflicts still exist $[1,3]$. Our meta-analysis showed that the A1762T/G1764A

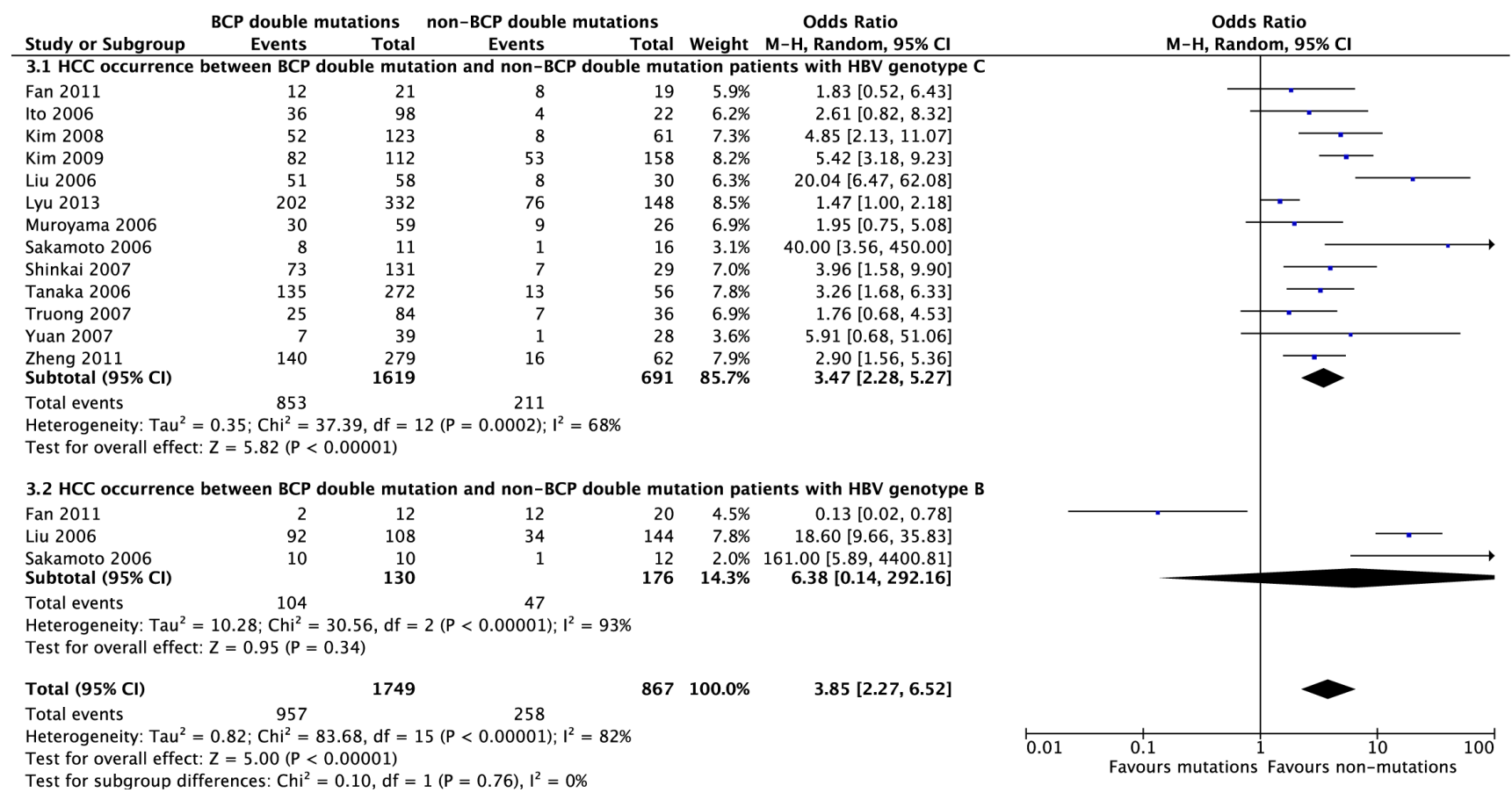

Figure 3: HCC occurrence between BCP A1762T/G1764A dual mutation and non-BCP dual mutation patients with HBV genotype $C$ and genotype $B$. 
dual mutation was present at statistically significantly higher frequencies in $\mathrm{HCC}$ patients than in non-HCC controls, including LC, CHB and ASC patients. As the disease progressed, the risk of the $\mathrm{A} 1762 \mathrm{~T} / \mathrm{G} 1764 \mathrm{~A}$ dual mutation in ASC, CHB, LC and HCC patients increased. Therefore, we hypothesized that A1762T/G1764A dual mutation might play a vital role in promoting disease progression in chronic HBV infection. Several previous case series have also shown a higher frequency of BCP T1762/A1764 mutation in patients with cirrhosis than in inactive carriers or patients with chronic hepatitis [16, 30, 58]. Our results confirmed this observation. However, the BCP A1762T/G1764A dual mutation is increasingly more prevalent as chronic $\mathrm{HBV}$ infection progresses from the asymptomatic HBsAg carrier state to liver cirrhosis or $\mathrm{HCC}$, indicating that these mutations accumulate before the diagnosis of HCC. This finding suggests that BCP dual mutation may be a promising biomarker for predicting the clinical outcomes of patients with chronic HBV infection, particularly in terms of predicting whether they will develop HCC. Additionally, we performed a subgroup analysis that revealed no statistically significant difference in terms of the frequency of A1762T/G1764A dual mutations in liver cirrhotic HCC and non-cirrhotic HCC patients. Thus, we assumed that BCP A1762T/G1764A dual mutations might promote hepatocarcinogenesis even without progression to cirrhosis. Because the samples of non-cirrhotic patients with HCC in this investigation were relatively small, this hypothesis must be proven based on future studies with larger patient cohorts.

HBV genotype is associated with the risk of HCC. One possible reason for this association is that $\mathrm{HBV}$ mutations may be more common in some HBV genotypes than in others [2]. In this research, we found that chronic HBV-infected patients with genotype B had a significantly lower risk of A1762T/G1764A dual mutations compared with those with genotype $\mathrm{C}$. In $\mathrm{HCC}$, patients with HBV genotype C suffered higher A1762T/G1764A dual mutations compared with those with genotype B. Previous reports have shown that patients with genotype $\mathrm{C}$ infection have a higher positive rate of $\mathrm{HBeAg}$, more severe liver disease and higher risk of developing HCC [30, 59-61]. On the basis of previous research and our results, we suggested that HBV genotype $\mathrm{C}$ patients tend to have a higher proportion of BCP T1762/A1764 mutations in conjunction with chronic $\mathrm{HBV}$ infection, including $\mathrm{HCC}$ $[31,58]$.

It has been suggested that the A1762T/G1764A

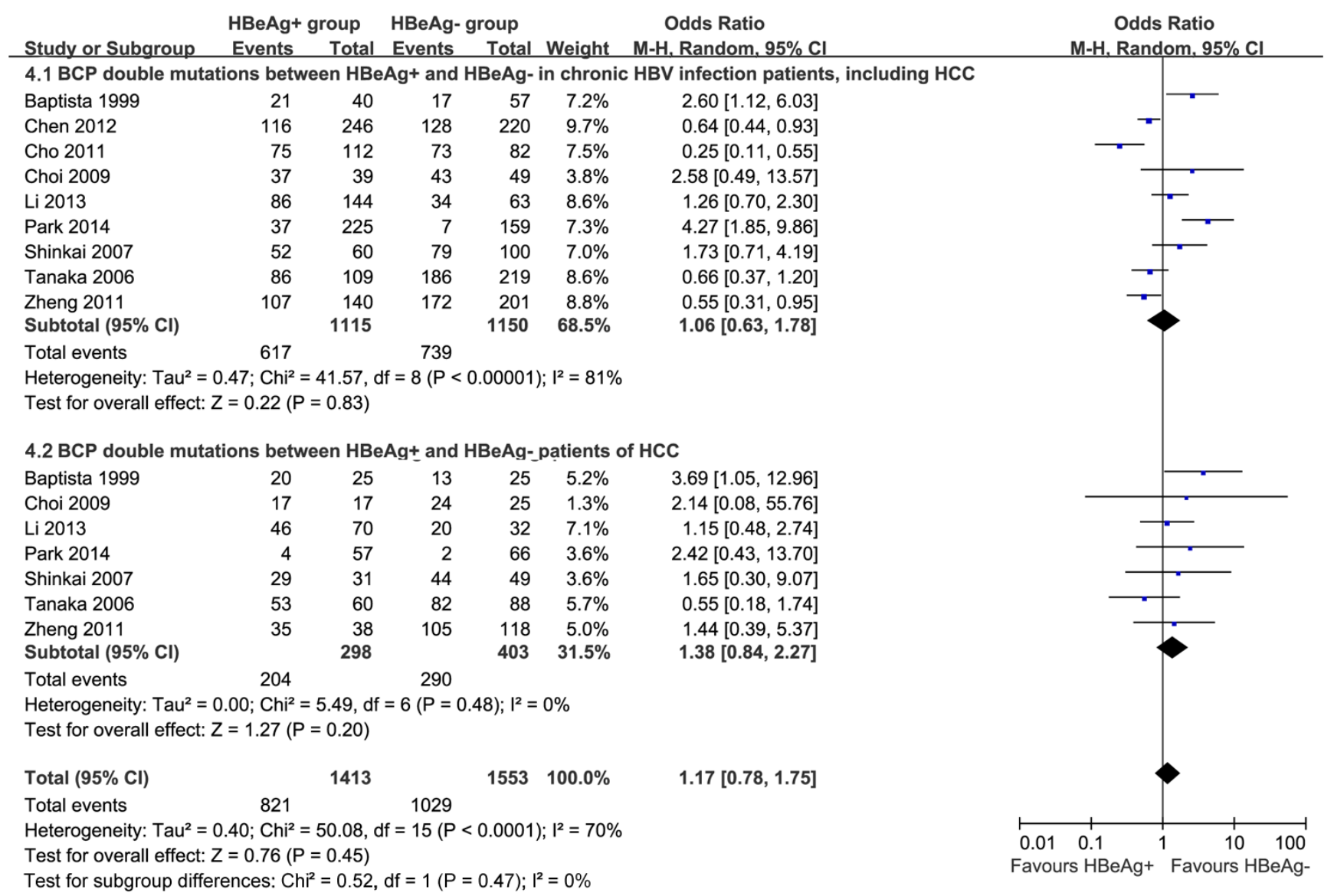

Figure 4: Comparison of BCP A1762T/G1764A dual mutations grouped by HBeAg status from chronic HBV infection patients, including HCC. 
double mutation in the $\mathrm{BCP}$ region can reduce the synthesis of $\mathrm{HBeAg}$ and enhance viral replication. However, this analysis found no significance of BCP A1762T/G1764A mutations from HBeAg-positive and $\mathrm{HBeAg}$-negative chronic $\mathrm{HBV}$-infected patients. The same finding was true for HCC patients. When introduced into wild-type HBV genomes, the BCP dual mutation indeed decreased $\mathrm{HBeAg}$ expression and enhanced viral genome replication of about twofold [60, 62]. Transfection studies have shown that the $\mathrm{T} 1762 \mathrm{~A} / \mathrm{G} 1764 \mathrm{~A}$ dual mutations decrease the level of pre-C mRNA by $50 \%$ to $70 \%$, thereby inhibiting $\mathrm{HBeAg}$ production. A previous report showed that $\mathrm{HBeAg}$ titers are closely correlated with $\mathrm{BCP}$ mutation, and $\mathrm{HBeAg}$-positive patients of genotype $\mathrm{C}$ infection had a higher prevalence of the A1762T/G1764A mutations [63]. Although no difference of BCP dual mutations was found in our meta-analysis, further research focusing on the mechanisms and the relationship between BCP mutation and HBeAg status is needed.

This meta-analysis had the following limitations. First, patients in the included studies had different HBV genotypes, different ethnicities, leading to significant heterogeneity; second, most of the included studies had small samples, with mid- to low-quality designs. In the future, high-quality, well-designed research focused on the mechanisms of BCP dual mutation in the progression of chronic HBV infection and HCC must be performed.

Based on our results, we could conclude that $\mathrm{BCP}$ A1762T/G1764A dual mutations are associated with disease progression and HCC occurrence in chronic $\mathrm{HBV}$-infected patients. Additionally, this mutation might promote hepatocarcinogenesis even without progression to cirrhosis. Considered the frequency ratio of $\mathrm{A} 1762 \mathrm{~T} /$ G1764A dual mutation from ASC, CHB, LC and HCC, we suggested that $\mathrm{BCP}$ dual mutation should be screened in the $\mathrm{CHB}$ and $\mathrm{LC}$ patients.

\section{MATERIALS AND METHODS}

\section{Search strategy and study selection}

We searched PubMed, Ovid, Web of Science, and Cochrane Library databases for studies published to June 1, 2015. The following medical subject headings were used: "hepatocellular carcinoma;" "hepatitis B virus X protein;" "mutation;" "basal core promoter;" "A1762T;" "G1764A;" and "variation." Electronic searches were supplemented with manual searches of reference lists used in all retrieved review articles, primary studies, and abstracts from meetings to identify other studies not found in the electronic searches. The literature was searched by two authors (Z Yang and L Zhuang) independently.

Two authors independently selected studies and discussed them with each other when inconsistencies were found. Articles that satisfied the following criteria were included: (1) case-control or cohort studies, (2) $\mathrm{HCC}$ and control subjects, including ASC, CHB or LC patients, (3) BCP A1762T/G1764A dual mutations (for HBV mutation), (4) HCC outcomes, and (5) available full texts. If the duration and sources of the study population recruitment overlapped by more than $30 \%$ in two or more papers by the same authors, we only included the most recent study or the study with the larger number of HCC patients. The following exclusion criteria were applied: (1) studies that included patients who were coinfected with hepatitis A, C, D, E virus or human immunodeficiency virus, had alcohol-related liver diseases, or had previously received antiviral treatments, (2) studies without control subjects, and (3) studies that only investigated A1762T or G1764A single mutations.

\section{Data extraction and methodological quality assessment}

In our evaluation of the BCP A1762T/G1764A dual mutant, subjects with either a single mutation or a deletion at either site were not included in the analysis. Two researchers independently read the full texts and extracted the following information: publication data; study design; sample size; HBV genotypes; country or area; and study matching factors. The methodological qualities of the included studies were assessed according to the report by Liu et al. [64]. A 12-point scoring system was used that was based on factors that indicated goodquality observational studies, as shown in Table 1. Two authors (ZG Yang and LP Zhuang) independently assessed the study quality, and inconsistency was discussed with another reviewer-author (X Chen), who acted as an arbiter.

\section{Definitions}

All diagnoses should be made according to the guidelines. ASC were defined as being seropositive for HBsAg for at least 6 months, having no evidence of LC or HCC based on the clinical criteria and undergoing ultrasound examination, with normal alanine aminotransferase (ALT). CHB was defined as being seropositive for HBsAg for at least 6 months, having persistent or intermittently elevated ALT levels or a liver biopsy showing chronic hepatitis with moderate or severe necroinflammation, with no clinical evidence of LC. The patients with LC were diagnosed by histologic analysis of liver biopsy specimens or by findings of repeated ultrasonography that were suggestive of cirrhosis and supplemented with clinical criteria indicating portal hypertension (i.e., the presence of ascites, thrombocytopenia, and esophageal varices). HCC was defined by at least one of the following criteria: (1) liver biopsy or (2) elevated alpha-fetoprotein levels and 
sonography, computed tomography or magnetic resonance imaging evidence.

\section{Statistical methods}

The effect measures of interest were odds ratios (ORs) and the corresponding 95\% confidence intervals (CIs). Heterogeneity across studies was informally assessed by visually inspecting forest plots and then formally estimated by Cochran's Q test in which chisquared distribution was used to make inferences regarding the null hypothesis of homogeneity (considered significant at $\mathrm{P}<0.10$ ). A rough guide to our interpretation of $\mathrm{I}^{2}$ follows:

- $0 \%$ to $40 \%$ shows that heterogeneity may not be important

- $30 \%$ to $60 \%$ corresponds to moderate heterogeneity

- $50 \%$ to $90 \%$ indicates substantial heterogeneity

- $75 \%$ to $100 \%$ indicates considerable heterogeneity $[65,66]$

If the eligibility of some studies in the metaanalysis was uncertain because of missing information, a sensitivity analysis was performed by conducting the meta-analysis twice: in the first meta-analysis, all studies were included; in the second meta-analysis, only studies that were definitely eligible were included. A fixedeffects model was initially used for our meta-analyses; a random-effects model was then used in the presence of heterogeneity. Description analysis was performed when the quantitative data could not be pooled. Review Manager software, version 5.1, was used for data analysis. All statistical tests were two-tailed, and differences with $P$ $<0.05$ were considered statistically significant.

\section{ACKNOWLEDGMENTS}

This work was not supported by any pharmaceutical company or government agency or grants from other sources.

\section{CONFLICTS OF INTEREST}

There is no conflict of interest.

\section{Editorial note}

This paper has been accepted based in part on peerreview conducted by another journal and the authors' response and revisions as well as expedited peer-review in Oncotarget.

\section{REFERENCES}

1. Bouchard MJ, Schneider RJ. The enigmatic $X$ gene of hepatitis B virus. J Virol. 2004;78: 12725-12734.

2. Liao Y, Hu X, Chen J, Cai B, Tang J, Ying B, Wang H, Wang L. Precore mutation of hepatitis B virus may contribute to hepatocellular carcinoma risk: evidence from an updated meta-analysis. PLoS One. 2012; 7: e38394.

3. Li W, Goto K, Matsubara Y, Ito S, Muroyama R, Li Q, Kato $\mathrm{N}$. The characteristic changes in hepatitis $\mathrm{B}$ virus $\mathrm{x}$ region for hepatocellular carcinoma: a comprehensive analysis based on global data. PLoS One. 2015; 10: e0125555.

4. Asim M, Malik A, Sarma MP, Polipalli SK, Begum N, Ahmad I, Khan LA, Husain SA, Akhtar N, Husain S, Thayumanavan L, Singla R, Kar P. Hepatitis B virus BCP, Precore/core, $\mathrm{X}$ gene mutations/genotypes and the risk of hepatocellular carcinoma in India. J Med Virol. 2010; 82: 1115-1125.

5. Bahramali G, Sadeghizadeh M, Amini-Bavil-Olyaee S, Alavian SM, Behzad-Behbahani A, Adeli A, Aghasadeghi MR, Amini S, Mahboudi F. Clinical, virologic and phylogenetic features of hepatitis B infection in Iranian patients. World J Gastroenterol. 2008;14: 5448-5453.

6. Bai X, Zhu Y, Jin Y, Guo X, Qian G, Chen T, Zhang J, Wang J, Groopman JD, Gu J, Tu H. Temporal acquisition of sequential mutations in the enhancer II and basal core promoter of HBV in individuals at high risk for hepatocellular carcinoma. Carcinogenesis. 2011;32: 63-68.

7. Baptista M, Kramvis A, Kew MC. High prevalence of 1762(T) 1764(A) mutations in the basic core promoter of hepatitis B virus isolated from black Africans with hepatocellular carcinoma compared with asymptomatic carriers. Hepatology. 1999; 29: 946-953.

8. Bläckberg J, Kidd-Ljunggren K. Mutations within the hepatitis B virus genome among chronic hepatitis B patients with hepatocellular carcinoma. J Med Virol. 2003; 71:1823.

9. Chen BF, Liu CJ, Jow GM, Chen PJ, Kao JH, Chen DS. High prevalence and mapping of pre-S deletion in hepatitis B virus carriers with progressive liver diseases. Gastroenterology. 2006; 130: 1153-1168.

10. Chen $\mathrm{CH}$, Changchien $\mathrm{CS}$, Lee $\mathrm{CM}$, Hung $\mathrm{CH}, \mathrm{Hu} \mathrm{TH}$, Wang JH, Wang JC, Lu SN. Combined mutations in pre-s/ surface and core promoter/precore regions of hepatitis B virus increase the risk of hepatocellular carcinoma: a casecontrol study. J Infect Dis. 2008; 198: 1634-1142.

11. Chen $\mathrm{CH}$, Changchien CS, Lee CM, Tung WC, Hung $\mathrm{CH}, \mathrm{Hu} \mathrm{TH}$, Wang JH, Wang JC, Lu SN. A study on sequence variations in pre-S/surface, $\mathrm{X}$ and enhancer II/ core promoter/precore regions of occult hepatitis B virus in non-B, non-C hepatocellular carcinoma patients in Taiwan. Int J Cancer. 2009; 125: 621-629.

12. Chen Y, Yu D, Zhang W, Qiu C, Xiang G, Dai W, Wu S, Wang X. HBV Subgenotype C2 Infection, A1762T/ 
G1764A Mutations May Contribute To Hepatocellular Carcinoma with Cirrhosis in Southeast China. Iran J Public Health. 2012; 41: 10-18.

13. Cho EY, Choi CS, Cho JH, Kim HC. Association between Hepatitis B Virus X Gene Mutations and Clinical Status in Patients with Chronic Hepatitis B Infection. Gut Liver. 2011;5: 70-76.

14. Choi CS, Cho EY, Park R, Kim SJ, Cho JH, Kim HC. X gene mutations in hepatitis B patients with cirrhosis, with and without hepatocellular carcinoma. J Med Virol. 2009; 81: 1721-1725.

15. Chou YC, Yu MW, Wu CF, Yang SY, Lin CL, Liu CJ, Shih WL, Chen PJ, Liaw YF, Chen CJ. Temporal relationship between hepatitis B virus enhancer II/basal core promoter sequence variation and risk of hepatocellular carcinoma. Gut. 2008; 57: 91-97.

16. Chu CM, Lin CC, Chen YC, Jeng WJ, Lin SM, Liaw YF. Basal core promoter mutation is associated with progression to cirrhosis rather than hepatocellular carcinoma in chronic hepatitis B virus infection. Br J Cancer. 2012; 107: 20102015.

17. Constantinescu I, Dinu AA, Boscaiu V, Niculescu M. Hepatitis B virus core promoter mutations in patients with chronic hepatitis B and hepatocellular carcinoma in bucharest, romania. Hepat Mon. 2014; 14: e22072.

18. Datta S, Ghosh A, Dasgupta D, Ghosh A, Roychoudhury S, Roy G, Das S, Das K, Gupta S, Basu K, Basu A, Datta S, Chowdhury A, et al. Novel point and combomutations in the genome of hepatitis B virus-genotype D: characterization and impact on liver disease progression to hepatocellular carcinoma. PLoS One. 2014; 9: e110012.

19. Elkady A, Tanaka Y, Kurbanov F, Oynsuren T, Mizokami M. Virological and clinical implication of core promoter C1752/V1753 and T1764/G1766 mutations in hepatitis B virus genotype D infection in Mongolia. J Gastroenterol Hepatol. 2008; 23: 474-481.

20. Fan W, Shi B, Wei H, Du G, Song S. Comparison of hepatitis $\mathrm{B} X$ gene mutation between patients with hepatocellular carcinoma and patients with chronic hepatitis B. Virus Genes. 2011; 42: 162-170.

21. Guo X, Jin Y, Qian G, Tu H. Sequential accumulation of the mutations in core promoter of hepatitis B virus is associated with the development of hepatocellular carcinoma in Qidong, China. J Hepatol. 2008; 49: 718-725.

22. Ito K, Tanaka Y, Orito E, Sugiyama M, Fujiwara K, Sugauchi F, Kato T, Tokita H, Izumi N, Kato M, Yuen MF, Lai CL, Gish RG, et al. T1653 mutation in the box alpha increases the risk of hepatocellular carcinoma in patients with chronic hepatitis $\mathrm{B}$ virus genotype $\mathrm{C}$ infection. Clin Infect Dis. 2006; 42: 1-7.

23. Jang JW, Lee YC, Kim MS, Lee SY, Bae SH, Choi JY, Yoon SK. A 13-year longitudinal study of the impact of double mutations in the core promoter region of hepatitis $\mathrm{B}$ virus on $\mathrm{HBe} \mathrm{Ag}$ seroconversion and disease progression in patients with genotype $\mathrm{C}$ chronic active hepatitis. J Viral Hepat. 2007; 14: 169-175.

24. Kao JH, Liu CJ, Jow GM, Chen PJ, Chen DS, Chen BF. Fine mapping of hepatitis $\mathrm{B}$ virus pre-S deletion and its association with hepatocellular carcinoma. Liver Int. 2012; 32: 1373-1381.

25. Kim HJ, Park JH, Jee Y, Lee SA, Kim H, Song BC, Yang S, Lee M, Yoon JH, Kim YJ, Lee HS, Hwang ES, Kook $\mathrm{YH}$, et al. Hepatitis B virus X mutations occurring naturally associated with clinical severity of liver disease among Korean patients with chronic genotype C infection. J Med Virol. 2008; 80: 1337-1343.

26. Kim JK, Chang HY, Lee JM, Baatarkhuu O, Yoon YJ, Park JY, Kim do Y, Han KH, Chon CY, Ahn SH. Specific mutations in the enhancer II/core promoter/precore regions of hepatitis B virus subgenotype C2 in Korean patients with hepatocellular carcinoma. J Med Virol. 2009; 81: 10021008.

27. Kuang SY, Lekawanvijit S, Maneekarn N, Thongsawat S, Brodovicz K, Nelson K, Groopman JD. Hepatitis B 1762T/1764A mutations, hepatitis $\mathrm{C}$ infection, and codon 249 p53 mutations in hepatocellular carcinomas from Thailand. Cancer Epidemiol Biomarkers Prev. 2005; 14: 380-384.

28. Lee JH, Han KH, Lee JM, Park JH, Kim HS. Impact of hepatitis $\mathrm{B}$ virus (HBV) $\mathrm{x}$ gene mutations on hepatocellular carcinoma development in chronic HBV infection. Clin Vaccine Immunol. 2011; 18: 914-921.

29. Li W, Chen G, Yu X, Shi Y, Peng M, Wei J. Accumulation of the mutations in basal core promoter of hepatitis $\mathrm{B}$ virus subgenotype $\mathrm{C} 1$ increase the risk of hepatocellular carcinoma in Southern China. Int J Clin Exp Pathol. 2013; 6: 1076-1085.

30. Lin CL, Liao LY, Wang CS, Chen PJ, Lai MY, Chen DS, Kao JH. Basal core-promoter mutant of hepatitis B virus and progression of liver disease in hepatitis B e antigennegative chronic hepatitis B. Liver Int. 2005; 25: 564-570.

31. Liu CJ, Chen BF, Chen PJ, Lai MY, Huang WL, Kao JH, Chen DS. Role of hepatitis B viral load and basal core promoter mutation in hepatocellular carcinoma in hepatitis B carriers. J Infect Dis. 2006; 193: 1258-1265.

32. Livingston SE, Simonetti JP, McMahon BJ, Bulkow LR, Hurlburt KJ, Homan CE, Snowball MM, Cagle HH, Williams JL, Chulanov VP. Hepatitis B virus genotypes in Alaska Native people with hepatocellular carcinoma: preponderance of genotype F. J Infect Dis. 2007; 195: 5-11.

33. Lyu H, Lee D, Chung YH, Kim JA, Lee JH, Jin YJ, Park W, Mathews P, Jaffee E, Zheng L, Yu E, Lee YJ. Synergistic effects of A1896, T1653 and T1762/A1764 mutations in genotype $\mathrm{c} 2$ hepatitis B virus on development of hepatocellular carcinoma. J Viral Hepat. 2013; 20: 219224.

34. Malik A, Singhal DK, Albanyan A, Husain SA, Kar P. Hepatitis B virus gene mutations in liver diseases: a report 
from New Delhi. PLoS One. 2012; 7: e39028.

35. Muroyama R, Kato N, Yoshida H, Otsuka M, Moriyama M, Wang Y, Shao RX, Dharel N, Tanaka Y, Ohta M, Tateishi R, Shiina S, Tatsukawa M, et al. Nucleotide change of codon 38 in the $\mathrm{X}$ gene of hepatitis $\mathrm{B}$ virus genotype $\mathrm{C}$ is associated with an increased risk of hepatocellular carcinoma. J Hepatol. 2006; 45: 805-812.

36. Panigrahi R, Biswas A, Banerjee A, Singh SP, Panigrahi MK, Roque-Afonso AM, Das HS, Mahapatra PK, Chakrabarti S, Chakravarty R. Subgenotype D5, BCP and MHR mutations in hepatic complications among hepatitis $B$ virus infected patients from Orissa, India. Infect Genet Evol. 2012; 12: 1622-1629.

37. Park YM, Jang JW, Yoo SH, Kim SH, Oh IM, Park SJ, Jang YS, Lee SJ. Combinations of eight key mutations in the $\mathrm{X} / \mathrm{preC}$ region and genomic activity of hepatitis $\mathrm{B}$ virus are associated with hepatocellular carcinoma. J Viral Hepat. 2014; 21: 171-177.

38. Qu LS, Zhu J, Liu TT, Shen XZ, Chen TY, Ni ZP, Ni RZ, $\mathrm{Lu} \mathrm{CH}$. Effect of combined mutations in the enhancer II and basal core promoter of hepatitis B virus on development of hepatocellular carcinoma in Qidong, China. Hepatol Res. 2014; 44: 1186-1195.

39. Sakamoto T, Tanaka Y, Orito E, Co J, Clavio J, Sugauchi F, Ito K, Ozasa A, Quino A, Ueda R, Sollano J, Mizokami M. Novel subtypes (subgenotypes) of hepatitis B virus genotypes $\mathrm{B}$ and $\mathrm{C}$ among chronic liver disease patients in the Philippines. J Gen Virol. 2006; 87: 1873-1882.

40. Shinkai N, Tanaka Y, Ito K, Mukaide M, Hasegawa I, Asahina Y, Izumi N, Yatsuhashi H, Orito E, Joh T, Mizokami M. Influence of hepatitis B virus $\mathrm{X}$ and core promoter mutations on hepatocellular carcinoma among patients infected with subgenotype C2. J Clin Microbiol. 2007; 45: 3191-3197.

41. Song LH, Duy DN, Binh VQ, Luty AJ, Kremsner PG, Bock CT. Low frequency of mutations in the $\mathrm{X}$ gene, core promoter and precore region of hepatitis B virus infected Vietnamese. J Viral Hepat. 2005; 12: 160-167.

42. Tanaka Y, Mukaide M, Orito E, Yuen MF, Ito K, Kurbanov F, Sugauchi F, Asahina Y, Izumi N, Kato M, Lai CL, Ueda R, Mizokami M. Specific mutations in enhancer II/core promoter of hepatitis B virus subgenotypes $\mathrm{C} 1 / \mathrm{C} 2$ increase the risk of hepatocellular carcinoma. J Hepatol. 2006; 45: 646-653.

43. Tangkijvanich $\mathrm{P}$, Sa-Nguanmoo $\mathrm{P}$, Mahachai V, Theamboonlers A, Poovorawan Y. A case-control study on sequence variations in the enhancer II/core promoter/ precore and $\mathrm{X}$ genes of hepatitis $\mathrm{B}$ virus in patients with hepatocellular carcinoma. Hepatol Int. 2010; 4: 577-584.

44. Tong MJ, Blatt LM, Kao JH, Cheng JT, Corey WG. Basal core promoter T1762/A1764 and precore A1896 gene mutations in hepatitis B surface antigen-positive hepatocellular carcinoma: a comparison with chronic carriers. Liver Int. 2007; 27: 1356-1363.
45. Tong MJ, Huynh TT, Siripongsakun S. Familial clustering of hepatocellular carcinoma in HBsAg-positive patients in the United States. Hepatol Int. 2013; 7: 1019-1029.

46. Truong BX, Yano Y, Seo Y, Phuong TM, Tanaka Y, Kato H, Miki A, Utsumi T, Azuma T, Trach NK, Mizokami M, Hayashi Y, Kasuga M. Variations in the core promoter/precore region in HBV genotype $\mathrm{C}$ in Japanese and Northern Vietnamese patients. J Med Virol. 2007; 79: 1293-1304.

47. Utama A, Purwantomo S, Siburian MD, Dhenni R, Gani RA, Hasan I, Sanityoso A, Miskad UA, Akil F, Yusuf I, Achwan WA, Soemohardjo S, Lelosutan SA, et al. Hepatitis $B$ virus subgenotypes and basal core promoter mutations in Indonesia. World J Gastroenterol. 2009; 15: 4028-4036.

48. Wang Z, Tanaka Y, Huang Y, Kurbanov F, Chen J, Zeng G, Zhou B, Mizokami M, Hou J. Clinical and virological characteristics of hepatitis B virus subgenotypes Ba, C1, and C2 in China. J Clin Microbiol. 2007; 45: 1491-1496.

49. Xu L, Qian G, Tang L, Su J, Wang JS. Genetic variations of hepatitis B virus and serum aflatoxin-lysine adduct on high risk of hepatocellular carcinoma in Southern Guangxi, China. J Hepatol. 2010; 53: 671-676.

50. Yin J, Xie J, Liu S, Zhang H, Han L, Lu W, Shen Q, Xu G, Dong H, Shen J, Zhang J, Han J, Wang L, et al. Association between the various mutations in viral core promoter region to different stages of hepatitis B, ranging of asymptomatic carrier state to hepatocellular carcinoma. Am J Gastroenterol. 2011; 106: 81-92.

51. Yuan J, Zhou B, Tanaka Y, Kurbanov F, Orito E, Gong Z, Xu L, Lu J, Jiang X, Lai W, Mizokami M. Hepatitis B virus (HBV) genotypes/subgenotypes in China: mutations in core promoter and precore/core and their clinical implications. J Clin Virol. 2007; 39: 87-93.

52. Yuan JM, Ambinder A, Fan Y, Gao YT, Yu MC, Groopman JD. Prospective evaluation of hepatitis B 1762(T)/1764(A) mutations on hepatocellular carcinoma development in Shanghai, China. Cancer Epidemiol Biomarkers Prev. 2009; 18: 590-594.

53. Zhang F, Shao YF, Gao JD, Xu Y, Liu GT, Xu LB, Wu ZY, Gao WH, Sun ZT. Risk features of HBV in human hepatocarcinogenesis: a nested case-controlled study. Zhonghua Wai Ke Za Zhi. 2007; 45: 1482-1484.

54. Zheng JX, Zeng Z, Zheng YY, Yin SJ, Zhang DY, Yu YY, Wang F. Role of hepatitis B virus base core and precore/ core promoter mutations on hepatocellular carcinoma in untreated older genotype C Chinese patients. J Viral Hepat. 2011; 18: e423-431.

55. Zhu R, Zhang HP, Yu H, Li H, Ling YQ, Hu XQ, Zhu HG. Hepatitis B virus mutations associated with in situ expression of hepatitis B core antigen, viral load and prognosis in chronic hepatitis B patients. Pathol Res Pract. 2008; 204: 731-742.

56. Zhuang L, Xu L, Wang P, Jiang Y, Yong P, Zhang C, Zhang $\mathrm{H}$, Meng Z, Yang P. Na+/K+-ATPase $\alpha 1$ subunit, a novel therapeutic target for hepatocellular carcinoma. Oncotarget. 
2015; 6: 28183-93. doi: 10.18632/oncotarget.4726.

57. Yang Z, Zhang J, Lu Y, Xu Q, Tang B, Wang Q, Zhang W, Chen S, Lu L, Chen X. Aspartate aminotransferaselymphocyte ratio index and systemic immuneinflammation index predict overall survival in HBV-related hepatocellular carcinoma patients after transcatheter arterial chemoembolization. Oncotarget. 2015. 15; 6:43090-8 doi: 10.18632/oncotarget.5719.

58. Kao JH, Chen PJ, Lai MY, Chen DS. Basal core promoter mutations of hepatitis $\mathrm{B}$ virus increase the risk of hepatocellular carcinoma in hepatitis B carriers. Gastroenterology. 2003; 124: 327-334.

59. Kao JH, Chen PJ, Lai MY, Chen DS. Genotypes and clinical phenotypes of hepatitis B virus in patients with chronic hepatitis B virus infection. J Clin Microbiol. 2002; 40: 1207-1209.

60. Croagh CM, Desmond PV, Bell SJ. Genotypes and viral variants in chronic hepatitis B: A review of epidemiology and clinical relevance. World J Hepatol. 2015; 7: 289-303.

61. Yang HI, Yeh SH, Chen PJ, Iloeje UH, Jen CL, Su J, Wang LY, Lu SN, You SL, Chen DS, Liaw YF, Chen CJ; REVEAL-HBV Study Group. Associations between hepatitis B virus genotype and mutants and the risk of hepatocellular carcinoma. J Natl Cancer Inst. 2008; 100: 1134-1143.

62. Parekh S, Zoulim F, Ahn SH, Tsai A, Li J, Kawai S, Khan N, Trépo C, Wands J, Tong S. Genome replication, virion secretion, and e antigen expression of naturally occurring hepatitis B virus core promoter mutants. J Virol. 2003; 77: 6601-6612.

63. Qin Y, Zhang J, Mao R, Guo H, Yin Y, Wu X, Weng X, Wands J, Tong S. Prevalence of basal core promoter and precore mutations in Chinese chronic hepatitis B patients and correlation with serum HBeAG titers. J Med Virol. 2009; 81: 807-814.

64. Liu S, Zhang H, Gu C, Yin J, He Y, Xie J, Cao G. Associations between hepatitis $\mathrm{B}$ virus mutations and the risk of hepatocellular carcinoma: a meta-analysis. J Natl Cancer Inst. 2009;101: 1066-1082.

65. Higgins JPT, Green S (eds.). Cochrane Handbook for Systematic Reviews of Interventions version 5.1.0 (updated March 2011). The Cochrane Collaboration, 2011.available from: www.cochrane-handbook.org.

66. Higgins JP, Thompson SG. Quantifying heterogeneity in a meta-analysis. Stat Med. 2002; 21: 1539-1558. 